\title{
THE FOLIAR SPRAY APPLICATION OF SELECTED ORGANIC FERTILIZERS AND THEIR EFFECTS ON SELECTED PLANTS - A REVIEW
}

\author{
Priya Shukla ${ }^{1^{*}}$ \\ ${ }^{1}$ Department of Botany, \\ Bioinformatics and Climate Change Impacts \\ Management, \\ University School of Sciences, Gujarat \\ University, \\ Ahmadabad, Gujarat, \\ India.
}

\author{
Swati Jayswal ${ }^{2}$ \\ ${ }^{2}$ Department of Botany, \\ Bioinformatics and Climate Change Impacts \\ Management, \\ University School of Sciences, Gujarat \\ University, \\ Ahmadabad, Gujarat, \\ India.
}

\author{
Bharat Maitreya ${ }^{3}$ \\ ${ }^{3}$ Department of Botany, \\ Bioinformatics and Climate Change Impacts Management, \\ University School of Sciences, Gujarat University, \\ Ahmadabad, Gujarat, \\ India.
}

Article DOI: https://doi.org/10.36713/epra6555

\begin{abstract}
The organic fertilizer or manures like banana peel, coconut peat and waste milk tea (TW) are highly rich in nitrogen, potassium and phosphorus etc (Vu, H. T., et al., 2018; Khan, M.Z., et al., 2019; Sial, T.A., et al., 2019). The sandy soil is one of the most severe conditions which negatively affect the growth of plant. The aim of the study is to report the foliar spray effect of milk tea waste extract, banana peel extract, coconut peat extract, on the growth of coriander and spinach plants. In this analysis different pots for various organic fertilizers were used to check their effect on plant growth and to investigate the improvement of biochemical properties of sandy soil (Vu, H. T., et al., 2018; Khan, M.Z., et al., 2019; Sial, T.A., et al., 2019).According to review, using various fertilizers growth parameters like plant height, numbers of leaves, shoot moisture content, NPK content present selected in plants can be compared. This review describes the best organic fertilizer among banana peel, coconut peat and waste milk tea and their effect on the growth parameters of coriander and spinach plant.

KEYWORDS: Banana peel, Coconut peat, Waste milk tea, Fertilizer, Plants growth, Soil analysis.
\end{abstract}

\section{INTRODUCTION}

The continuous increase of the global population puts great pressure on the environment, food, and vegetable production (Sial, T.A., et al., 2019) to meet leafy plant production; vegetable crop production for future will put a stain on soil and water resource security in coming decades (Sofyan, E.T., et al., 2019) Fertilizer is any organic or inorganic material of natural or synthetics origin that is added to a soil to supply one or more plant nutrients essential to the growth of the vegetable crop (Ismail, M.M., et al., 2017). The use of organic fertilizer has long been recognized in 
agriculture as advantages for maintenance of plant and yield development and soil fertility; new approaches to the use of organic matter in farming improving the soil structure (Arancon et al., 2005).

The banana peel contains a high amount of antioxidants that are beneficial to our health in many ways (Farina et al., 2006). Nutrient values vary greatly among organic fertilizers (Sofyan, E.T., et al., 2019). The milk tea waste and coconut peat is a batter option for the strong root growth traits $[13,25]$. Cheapest and harmless materials can be used for the plant growth.

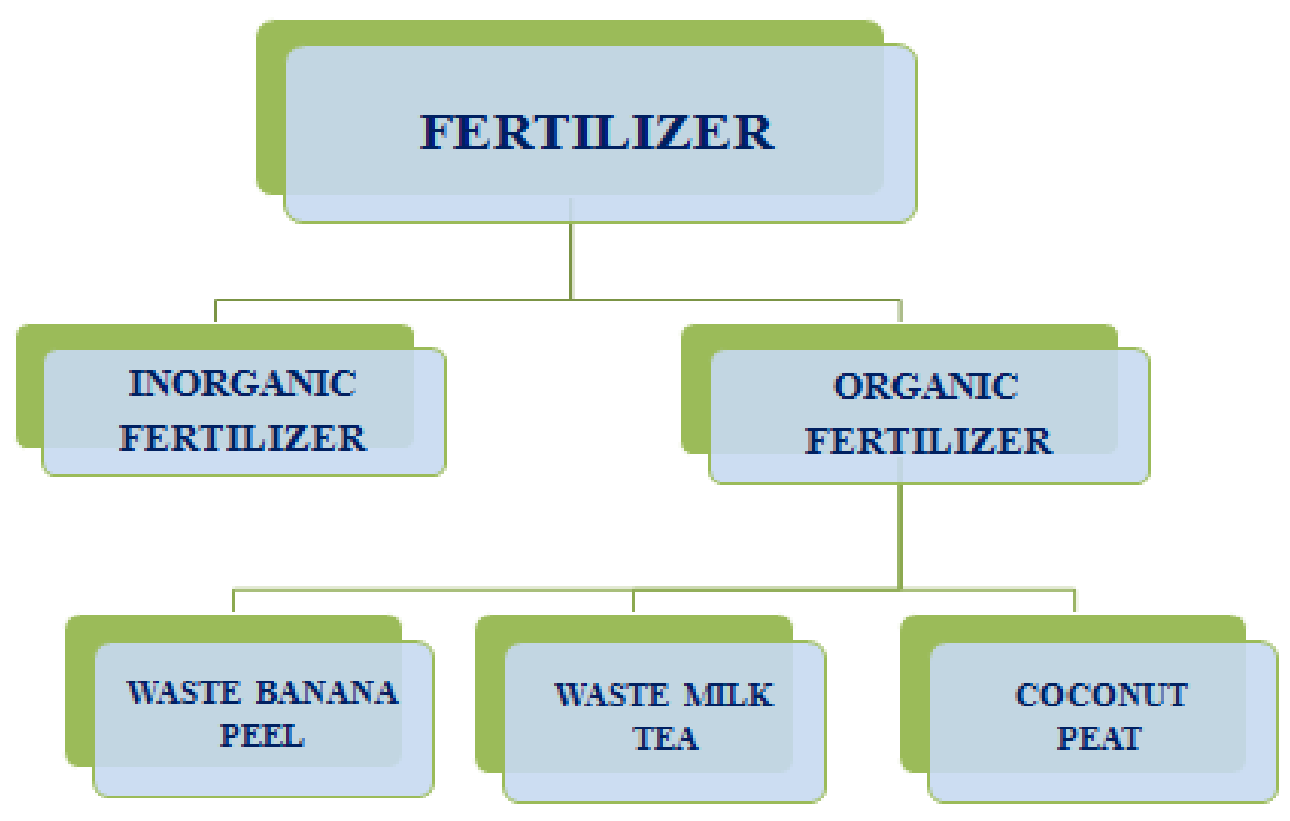

Figure 1. :-Types of selected organic fertilizers

\subsection{GERNAL CHARACTERISTICS OF THE BANANA PEEL}

Foods are essential for people with a large percentage. Banana peels are easily available agricultural waste that is being used as potential development (jariwala, H.J., et al., 2016). The banana peels use as organic fertilizer which is cheapest and harmless material (Mercy, S., et al., 2014). Banana peel helps to the medium of yeast, despite their rich carbohydrate content and other basic nutrients supporting yeast development (Mohapatra, D., et al., 2010). Based on research banana peel is non- toxic and environmentally friendly ash to compatible as matrix for producing plant (QADER, H. et al., 2019). In banana peels iron and zinc were found in higher concentration and other nutrients like potassium, magnesium, phosphorus, calcium, etc. present in banana peels (Nik Yusuf, N.A.A., et al., 2016).The cellulose, hemicelluloses, lignin and simple sugar also present in banana peel (Panwar, N. et al., 2015). The banana peel contains two important source antioxidant and carbonaceous matter (QADER, H. et al 2019; Vu, H.T., et al 2018). The dietary proteins, essential amino acid, fibers, polyunsaturated fatty acids present in banana peel (Agama-Acevedo, E., et al., 2016) The potassium helps plants to grow for their fruiting and flowering. The sodium in banana peels helps water flow between cells. 
ISSN (Online): 2455-3662

EPRA International Journal of Multidisciplinary Research (IJMR) - Peer Reviewed Journal Volume: 7 | Issue: 3 | March 2021|| Journal DOI: 10.36713/epra2013 || SJIF Impact Factor 2021:7.147 ||ISI Value: 1.188

\begin{tabular}{|c|c|c|}
\hline No. & Name of nutrients present in banana peel & Percentage \\
\hline 1. & starch & $13 \%$ \\
\hline 2 & Raw protein & $6-9 \%$ \\
\hline 3 & Raw fat & $3.8-11 \%$ \\
\hline 4 & lignin & $6-12 \%$ \\
\hline 5 & Pectin cellulose & $7.6-9.6 \%$ \\
\hline 6 & hemicelluloses & $6.4-9.4 \%$ \\
\hline
\end{tabular}

Table no.:-1 percentage of nutrients present in banana peel (Panwar, N. et al., 2015)

\subsection{GERNAL CHARACTRISTIC OF THE MILK TEA WASTE}

The milk tea waste is a batter option for the root traits, plant growth soil quality and nutrients contents of sandy soil. The milk tea applied as nutritional source for plants and sandy soil combined with chemical fertilizer (Sial, T.A., et al., 2019) Milk tea waste contains nutrients like nitrogen, potassium, phosphorus and low $\mathrm{C}$ : $\mathrm{N}$ ratio as compared to other organic amendments. It could be better amendment for sandy and low fertile soils. The TW breaks down and decomposes the soil (Sial, T.A., et al., 2019).

Due to the high growing trend of grain demand, supplements of NPK are required. Increasing the population, causing economic and environmental harm, In particular in sandy soil, there are high N, P, K loss due to leaching and other environment effect (Muningsih, R., et al., 2017). Nitrogen (N) is the element required by crops in greatest amount because the nitrogen is helpful to improvement of chlorophyll, an integral part of protein, and metabolic reaction (Khayum, N., et al., 2018). The organic fertilizer improves the soil quality, and $\mathrm{N}$ can be supplied under different soil texture for crop demands. High rate improved mild carbon fraction of soil c breakdown by nitrogen macro organism (Sial, T.A., et al., 2019). The phosphorus and potassium also helpful to improvement of plant growth and physiological effects for low fertility soil (Khayum, N., et al., 2018). If we can use excessive chemical fertilizer to become a weak soil quality and plant growth. So milk tea waste is the best option for crop production.

\subsection{GERNAL CHARACTERISTIC OF THE COCONUT PEAT}

The coconut palm (Cocos nucifera L.) is a member of the family Arecaceae (palm family). It is the only accepted species in the genus Coco (Noguera, P., et al., 1998). In modern year, Intensive crop production or cultivation using high-yielding multilateral crops with unbalanced fertilizer has mined rare native soil nutrients to support crop growth and production, Major soil ecological process in India have severely affected fertility and major soil production (Kurniawan, E. et al., 2019). Available data indicated that most of our soil fertility deteriorated over the year. In the sandy soil the soil quality is very low so used the organic fertilizer (coconut peat) for crop production (Awang, Y., et al 2009; Beozzi, S., et al; 2015). The many nutrients present in coconut peat like nitrogen, calcium, sodium, magnesium etc. nutrients (Da costa, et al; 2019; Khan, M.Z., et al., 2019).

The coconut peat has a high water holding capacity and has been traditionally used to improve the physical and chemical properties of soils. When one applied the coconut peat they help to improve moisture of soil, retention capacity and increase the available nutrient content, infiltration rate, total porosity and hydraulic conductivity of soil (Khan, M. Z., et al., 2019). Coconut peat as organic fertilizer can also help in decrease environmental pollution and the use of organic manure in soil. The Coconut peat promotes strong root growth (Mariotti, B., et al 2020).

\subsection{SELECTED PLANTS}

1.4.1. CORIANDER (Coriandrum sativum L.)

Coriander (Coriandrum sativum L.), is one of the most important spice and medicinal an annual 
herb in the family Apiaceae . It is also known as Chinese parsley, dhania or cilantro. It can be grown on a loamy soil and can also grow on heavy black soil (Da costa, R.S., et al., 2019). All parts of the plant are edible, but the fresh leaves and the dried seeds (as a spice) are the parts most traditionally used in cooking. Excessive use of inorganic fertilizers result in salt accumulation in soil and forced the plant to spend more energy to take the water from the soil and may results in low yield or the complete wilting of plant (Ismail, M.M., et al., 2017). It is cool season crop.

\subsubsection{SPINACH (Spinacia oleracea L.)}

Spinach (Spinacia oleracea L.) is an important leafy vegetable, of which the leaves and tender shoots are consumed fresh or processed (Citak, S., et al., 2010). Spinach is native to central Asia, most probably Persia (Iran). Spinach (Spinacia oleracea L.) belongs to the family Chenopodiaceae. Spinach is annual for leaf production and biennial for seed production (Adhikay, S. et al., 2012).

Spinach growing problems are related to growing spinach in the wrong season. Weather conditions may also be to blame for growing spinach. If the weather is too hot, seeds won't germinate, and if it's too cold, they could germinate much more slowly. Finally, keep soil evenly moist, as too little or too much water can also stop germination. An organic fertilizer high in nitrogen, the first number on the fertilizer package, will help produce dark, healthy plant leaves (Citak, S., et al., 2010).

\section{REVIEW OF THE LITERATURE}

Sail, T. A.et al., 2019 presented the treatment including practical usage of milk tea waste (TW) combined with chemical fertilizer. The application of organic amendments with inorganic fertilizers is an economically viable and environmentally comprehensive method to develop sustainable agriculture. The milk tea waste amendment combined with chemical fertilizer application can be used to improve the biochemical properties of sandy soil and wheat growth. The treatment control without amendment (T1), chemical fertilizer (T2), TW2.5\% + F (T3), $\mathrm{TW} 5 \%+\mathrm{F}$ (T4), and $\mathrm{TW} 10 \%+\mathrm{F}$ (T5) was followed. The result showed the highest chlorophyll and carotenoids, shoot, and root dry biomass. The highest root total length, root surface area, root volume and diameter were recorded for $\mathrm{T} 4$ among all treatments. The greatest uptake of $\mathrm{N}, \mathrm{P}, \mathrm{K}$, contents for T4 increased for the shoot by $68.9 \%, 58.3 \%$, and $57.1 \%$ and for the root by $65.7 \%, 34.3 \%$, and $47.4 \%$ compared to the control.

Mercy, S.et al., 2014 studied the effect of the fruit peels for the effective growth of plants and higher yield. Different fruit peels are used as pomegranate, orange, sweet lime, and banana. Fruit peels of banana, pomegranate, sweet lime and orange are highly rich in potash, ion, zinc, etc. Fruit peel powder formulation from the trace amount to higher amount is taken for the preparation of three formulations as formulation 1, formulation2, and formulation 3. The $1 \mathrm{~g}$ of fruit peel powder was taken in $100 \mathrm{ml}$ distilled water. And then $3 \mathrm{~g}$ of fruit peel powder was taken in $300 \mathrm{ml}$ distilled water and mixed thoroughly for the preparation of extract. Three formulation of fruit peel powder according to that were applied on soil and properly mixed for uniform distribution and water poured every day. As a result length of the plant was observed as lower in control and size of the leaves was increased in the plants which were grown on the soil having applied formulation.

Nik Yusuf, N. A. A., et al., 2016 performed the analysis of the soil to degrade the bio-polymer with the help of banana peel and waste egg shell. The banana peel and waste egg shell producing bio-mulching film is new innovation in agricultural industry. Biomulching film is a biodegradable plastics film that can help in increasingthe moisture content of soil and improving the soil ingredients in order to make the plants grow well. The thin film is produced by using the waste banana peels the reinforcement fiber. The banana peel with egg shell $10 \%$ were affected bio degradation in soil burial test.

QADER, H. 2019 studied the effect of the fruit peel like banana peel and orange peel as a natural fertilizer at dose $(0,4,8,12 \mathrm{~g} / \mathrm{pol})$ by different methods like as powder, powder extract, foliar spray on growth and development of chickpea plants. The powder method applied to each pot mixed with soil; in powder extract method $1 \mathrm{~g}$ fruit peel was taken in $100 \mathrm{ml}$ distilled water and mixed thoroughly for the preparation of extract. And this prepared extract was used as foliar spray for each plant. It was noticed that fruit peels had a positive effect on growth and development of chickpeas plants. The fruit peels of banana and orange by different methods such as powder peels, powder extract, foliar spray have effective roles in growth and development by enhancingvegetative growth such as plant height, number of branches, water content, stem diameter, yield characteristics and chemical contents. Foliar application of banana and orange peel has been proven more effective than other methods.

Khan, M. Z., Era, M. D.,et al., 2019 presented the effect on the coconut peat on growth and yield responses of ipomoea aquatica for pirojpur pot experiment and the experiment was laid to fit completely randomized design with five treatment 
[control (T0), $1000 \mathrm{~kg}$ coconut peat / ha (T1), $1500 \mathrm{~kg}$ coconut peat /ha (T2), 2000kg coconut peat /ha (T3), $25000 \mathrm{~kg}$ coconut peat/ha (T4) of coconut peat were compared with plants growth and yield with $0 \mathrm{~kg} / \mathrm{ha}$ coconut peat which was control for experiment and exhibited result having parameters like number of leaves per plant, root length per plant, shoot length per plant, fresh weigh per plant, dry weight per plant, moisture content per plant. At last the result of experiment showed that among the five treatments, comparatively $\mathrm{T} 4$ treatment has shown highest response of plant growth. The sequence of response was in the order $\mathrm{T} 4>\mathrm{T} 3>\mathrm{T} 2>\mathrm{T} 1>\mathrm{T} 0$.

Mariotti, B.et al., 2020 presented the peat is a non sustainable resource is still predominately used in forest nurseries. Peat and coir in combinations were used in the various fertilization treatments and it was found in the result that they affected above and below ground morphology and to a lesser extent the physiological trait of quercus seedling. In this experiment the three species were used to study the growth with the help of combination of pure coir and coconut peat, and they used $\mathrm{K}$ - enriched and $\mathrm{P}$ enriched fertilizers. In result they observed that the Kenriched fertilization promoted taller seedlings.

$\mathrm{Vu}, \mathrm{H}$. T.et al., 2018 presented the study on phenolic compound within banana peel. They investigated the chemical profile of banana peel. The phenolics within banana peels have been found to possess potent antioxidant and antimicrobial properties linked with various health benefits. This paper highlights the phenolic compounds as well as a major factor affecting their presence within the banana peel.

Awang, Y.et al., 2009 studied the effect of incorporation of coarser materials into coconut peat and presented that it could improve the aeration status of media. The selected chemical and physical characteristics of five types of growing media comprising of $(\mathrm{v} / \mathrm{v}) \quad 100 \%$ cocopeat, $70 \%$ cocopeat: $30 \%$ burnt rice hull, $70 \%$ coconut: $30 \%$ perlite, $70 \%$ coconut peat: $30 \%$ kenaf core fiber were determined and their suitability as growing media was tested using celosia cristata. The result of growth and flowering of celosia cristata were the greatest when grown in a mixture of $70 \%$ coco peat: $30 \%$ burnt rice hull and perhaps linked with a good balance in aeration and moisture of the media.

Muningsih, R.et al., 2017 presented the study to determine the nutrient content of liquid waste from the processing of green tea and green tea fermentation liquid waste used as organic fertilizer. The benefits to be obtained is to provide information on the nutrient content of the liquid waste from the processing of green tea and green tea fermentation liquid waste used as organic fertilizer. Results of analysis of liquid waste showed high content of organic $\mathrm{C}(5,7 \%)$ and nutrient content of macro and micro low i.e. N $0.24 \%$, P $0.06 \%$, $\mathrm{K} 0.69 \%$, Cu $1.63 \mathrm{ppm}$ and $\mathrm{Zn} 3.33 \mathrm{ppm}$. Liquid waste green tea as much as 1 liter with the addition of starter (EM-4) as much as $10 \mathrm{ml}$ has not shown the effect on the percentage of seedlings and growth of seedlings i.e. plant height, number of leaves and greenery.

Kurniawan, E.et al., 2019 studied the effect of fermentation time and influence of EM4 composition on nutrient quality insolid organic fertilizer (Coco peat husk waste And Goat of Dirt used). The results obtained based on the length of time of fermentation and Volume Effective Microorganism 4 (EM4) then obtained the best results at $60 \mathrm{ml}$ EM4 volume and $16^{\text {th }}$ day's fermentation time with $0.90 \%$ nitrogen content, $0.93 \%$ phosphorus, and potassium levels of $1.48 \%$. The longer and more EM4 volume the more nutrients it gets.

The uses of milk tea waste combined with chemical fertilizer as a soil nutrients sources for better wheat growth, root trait, and soil biochemical properties within sandy soil (Sail, T. A., et al., 2019). The application banana fruit peel powder extraction effective roles in growth and development of plants and foliar application is more effective than other methods (QADER, H. 2019). The coconut peat high rates increase the growth of Ipomoea aquatica and treatments gave significantly $(\mathrm{p}<0.05)$ difference in plant growth from the control (Khan, M. Z., Era, M. D.,et al., 2019).

\section{CONCLUSION}

This review represents the effect of organic fertilizers added to soil having physiological changes such as plant height, plant weight, fresh leaves weight, dry leaves weight, and shoot moisture content of plant growth. It also includes the comparison of the different fertilizers like coconut peat, cow milk waste, and banana peel. In addition to that morphological study of coriander plant and spinach plant having effect of selected organic fertilizers are also included. After the growth of plants comparison of the soil fertility in control soil and soil with different organic fertilizers is also pointed out. Overall, the all three organic fertilizers are proven as potential, cheap and rich sources of nutrients and phenolic compounds. 


\section{REFERENCES}

1. Adhikary, S. (2012). Vermicompost, the story of organic gold: A review.

2. Agama- Acevedo, E., Agama-Acevedo, J.A. Sañudo-Barajas, R. Vélez. De La Rocha, G.A. González-Aguilar \& L.A. Bello-Peréz (2016) Potential of plantain peels flour (MusaparadisiacaL.) as a source of dietary fiber and antioxidant compound, CYTA - Journalof Food, 14(1), 117-123.

3. Arancon, N.Q. \& Edwards, C. A. (2005, October). Effects of vermicomposts on plant growth.In International Symposium Workshop on Vermitechnology. Philippines.

4. Awang, Y., Shaharom, A. S., Mohamad, R. B., \&Selamat, A. (2009). Chemical and physical characteristics of cocopeat-based media mixtures and their effects on the growth and development of Celosia cristata. American journal of agricultural and biological sciences, 4(1), 63-71.

5. Beozzi, S.,Cabral, F., Vasconcelos, E., \&Ribeiro, $H$. M. (2015, September). Organic production of potted parsley and coriander in coconut coir amended with compost. In International Symposium on Growing Media, Composting and Substrate Analysis-SusGro2015 1168 (pp. 295-302).

6. Bustamante,M. A.,Paredes, C., Moral, R., Agulló, E., Pérez-Murcia, M. D., \& Abad, M. (2008). Composts from distillery wastes as peat substitutes for transplant production. Resources, Conservation and Recycling, 52(5), 792-799.

7. Citak, S., \&Sonmez, S. (2010). Effects of conventional and organic fertilization on spinach (Spinaceaoleracea L.) growth, yield, vitamin $C$ and nitrate concentration during two successive seasons. Scientiahorticulturae, 126(4), 415-420.

8. Da Costa, R. S., de Oliveira, L. K. B., dos Santos, J. L. G., Amorim, A. V., Cá, J., Ribeiro, M. C. C., \& de MM, B. (2019). Evaluation of different organic fertilizers in the sustainable cultive of coriander. Journal of Agricultural Science, 11(6).

9. De Kreij,C.,\&Van Leeuwen, G. J. L. (2001). Growth of pot plants in treated coir dust as compared to peat. Communications in soil science and plant analysis, 32(13-14), 2255-2265.

10. Gupta, C., Prakash, D., Gupta, S., \&Nazareno, M. A. (2019). Role of vermicomposting in agricultural waste management.In Sustainable Green Technologies for Environmental Management (pp. 283-295).Springer, Singapore.

11. Ismail,M. M., Moursy, A. A., \&Mousa, A. E. (2017). Effect of organic and inorganic $N$ fertilizer on growth and yield of chickpea (Cicer arietinum L.) grown on sandy soil using $15 \mathrm{~N}$ tracer. Bangladesh Journal of Botany, 46(1), 155161.

12. Jariwala, H.J., \& Syed, H. S. (2016). Study on use of fruit peels powder as a fertilizer.Retrieved from research gate : https://www. Research gate. Net/ publication/ 319329572 studies on use of fruit peels power as a fertilizer.

13. Khan, M. Z., Era, M. D., Islam, M. A., Khatun, R., Begum, A., \&Billah, S. M. (2019). Effect of Coconut Peat on the Growth and Yield Response of Ipomoea aquatica. American Journal of Plant Sciences, 10(03), 369.

14. Khayum, N., Anbarasu, S., \&Murugan, S. (2018). Biogas potential from spent tea waste: A laboratory scale investigation of co-digestion with cow manure. Energy, 165, 760-768.

15. Kurniawan, E. (2019, June). Utilization of Coco peatand Goat of Dirt in Marking of Solid Organic Fertilizer to Quality Macro Nutrient (NPK). In IOP Conference Series: Materials Science and Engineering (Vol. 543, No. 1, p. 012001). IOP Publishing.

16. Laghari, M., Mirjat, M. S., Hu, Z., Fazal, S., Xiao, B., Hu, M., \&Guo, D. (2015). Effects of biochar application rate on sandy desert soil properties and sorghum growth. Catena, 135, 313-320.

17. Mariotti, B., Martini, S., Raddi, S., Tani, A., Jacobs, D. F., Oliet, J. A., \&Maltoni, A. (2020). Coconut Coir as a Sustainable Nursery Growing Media for Seedling Production of the Ecologically Diverse Quercus Species. Forests, 11(5), 522.

18. Mercy,S.,Mubsira, B. S., \& Jenifer, I. (2014). Application of different fruit peels formulations as a natural fertilizer for plant growth. Int J SciTechnol Res, 3(1), 300-307.

19. Mohapatra,D.,Mishra, S., \&Sutar, N. (2010). Banana and its by-product utilisation: an overview.

20. Muningsih, R., \&Ciptadi, G. (2017). Potential of liquid waste green tea as organic fertilizer and its effect on tea seedling growth. Agrin: JournalPenelitianPertanian, 21(2), 140-145.

21. Nik Yusuf, N. A. A.,Rosly, E. S., Mohamed, M., Abu Bakar, B., Yusoff, M., Sulaiman, M. A., \& Ahmad, M. I. (2016). Waste banana peel and its potentialization in agricultural applications: Morphology overview. In Materials Science Forum (Vol. 840, pp. 394-398).

22. Noguera, P., Abad,M.,Noguera, V., Puchades, R., \&Maquieira, A. (1998, August). Coconut coir waste, a new and viable ecologically-friendly peat substitute. In XXV International Horticultural Congress, Part 7: Quality of Horticultural Products 517 (pp. 279-286).

23. 23. Panwar,N. (2015). Studies on physicochemical characteristics and fertility of soil by addition of banana peels-waste management. Int J Sci Res Dev, 3(1), 121-125.

24. QADER,H. (2019). Influence combination of Fruits Peel and Fertilizer Methods on growth and yield of Chickpea (Cicer areitinum) L. Plants. ZANCO Journal of Pure and Applied Sciences, 31(3), 45-51.

25. Sial, T. A., Liu, J., Zhao, Y., Khan, M. N., Lan, Z., Zhang, J., \&Rajpar, I. (2019). Co-application of milk tea waste and NPK fertilizers to improve sandy 
ISSN (Online): 2455-3662

EPRA International Journal of Multidisciplinary Research (IJMR) - Peer Reviewed Journal

Volume: 7 | Issue: 3 | March 2021|| Journal DOI: 10.36713/epra2013 || SJIF Impact Factor 2021:7.147 ||ISI Value: 1.188

soil biochemical properties and wheat growth. Molecules, 24(3), 423.

26. Sofyan, E.T., Sara, D. S., \&Machfud, Y. (2019, December). The effect of organic and inorganic fertilizer applications on $N$, P-uptake, K-uptake and yield of sweet corn (Zea mays saccharataSturt). In IOP Conference Series: Earth and
Environmental Science(Vol. 393, No. 1, p. 012021). IOP Publishing.

27. Vu, H. T., Scarlett, C. J., \&Vuong, Q. V. (2018). Phenolic compounds within banana peel and their potential uses: A review. Journal of Functional Foods, 40, 238-248. 